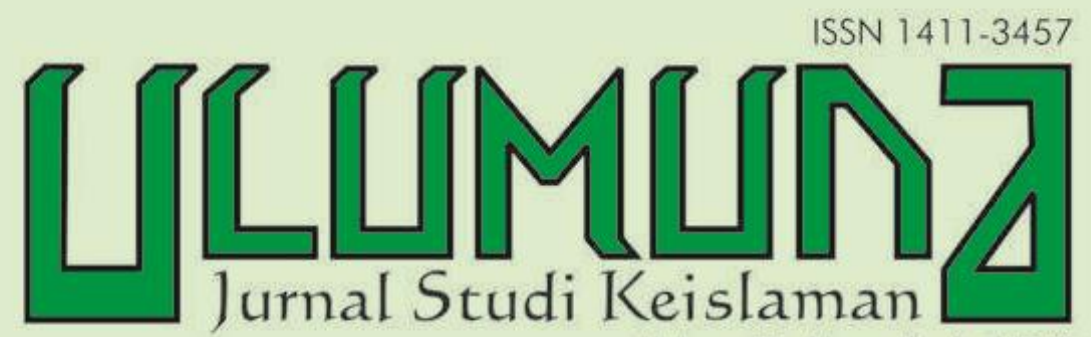

Volume $17 \cdot$ Nomor $1 \cdot$ Juni 2013

TERAKREDITASI B: SK Dirjen Dikti Kemdikbud Nomor: 56/DIKTI/Kep/2012, Tanggal 24 Juli 2012

MENCERNA AKAR FILSAFAT DALAM ISLAM Ismail Fahmi Arrauf PERKEMBANGAN PARADIGMA EPISTEMOLOGI DALAM FILSAFAT ISLAM Fathul Mufid EPISTEMOLOGI ISLAM: KEDUDUKAN WAHYU SEBAGAI SUMBER ILMU Anwar Muiahidin DARI ISLAMISASI ILMU MENUJU PENGILMUAN ISLAM: MELAWAN HEGEMONI EPISTEMOLOGI BARAT Ismail Toib dan Mukhlis INDUKTIVISME SEBAGAI BASIS PENGEMBANGAN ILMU PENGETAHUAN DALAM ISLAM Masdar Hilmy

PERTAUTAN ONTOLOGI FILSAFAT DAN TASAWUF: PERSPEKTIF TENTANG RELASI TUHAN, MANUSIA, DAN ALAM Hadarah Rajab PERTAUTAN EPISTEMOLOGI FILSAFAT DAN TASAWUF: TELAAH SISTEM PEMIKIRAN ABDUL HALIM MAHMUD Lalu Muchsin Effendi ETIKA DALAM FILSAFAT ISLAN:

PEMIKIRAN FILOSOF MUSLIM TENTANG KEBAHAGIAAN Mustain PEngembangan Sumber Daya MANusia DALAM PERSPEKTIF EPESTIMOLOGI FILSAFAT ISLAM Asep Kumiawan 


\section{DAFTAR ISI}

\section{Pedoman Transliterasi}

1-18 • Ismail Fahmi Arrauf,

"Mencerna Akar Filsafat dalam Islam"

19-40 • Fathul Mufid,

"Perkembangan Paradigma Epistemologi

dalam Filsafat Islam"

41-64 • Anwar Mujahidin

"Epistemologi Islam:

Kedudukan Wahyu Sebagai Sumber Ilmu"

65-96 • Ismail Toib dan Mukhlis

"Dari Islamisasi Ilmu Menuju Pengilmuan Islam:

Melawan Hegemoni Epistemologi Barat"

97-126 • Masdar Hilmy

"Induktivisme Sebagai Basis Pengembangan

Ilmu Pengetahuan dalam Islam"

127-152 • Hadarah Rajab

"Pertautan Ontologi Filsafat dan Tasawuf:

Telaah Relasi Tuhan, Manusia, dan Alam"

153-190 • Lalu Muchsin Effendi

"Pertautan Epistemologi Filsafat dan Tasawuf:

Telaah Sistem Pemikiran Abdul Halim Mahmud"

191-212• Mustain

"Etika dan Ajaran Moral Filsafat Islam:

Pemikiran Para Filosof Muslim tentang Kebahagiaan"

\section{3-230 • Asep Kurniawan}

Pengembangan Sumber Daya Manusia

dalam Perspektif Epestimologi Filsafat Islam

\section{APENDIKS}




\section{PEDOMAN TRANSLITERASI}

\begin{tabular}{|c|c|c|c|c|c|c|}
\hline 1 & $=$ & $\mathbf{a}$ & $\dot{\varepsilon}$ & $\dot{\varepsilon}$ & $=$ & $\mathrm{g}$ \\
\hline ب & $=$ & b & & ف & $=$ & $\mathrm{f}$ \\
\hline 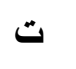 & $=$ & $\mathrm{t}$ & & ق & $=$ & $q$ \\
\hline$\dot{H}$ & $=$ & th & & ك5 & $=$ & $\mathbf{k}$ \\
\hline ج & $=$ & $\mathfrak{j}$ & & J & $=$ & 1 \\
\hline$\tau$ & $=$ & h & & م & $=$ & $\mathrm{m}$ \\
\hline$\dot{\tau}$ & $=$ & $\mathbf{k h}$ & & ن & $=$ & $\mathbf{n}$ \\
\hline د & $=$ & d & & و & $=$ & $\mathbf{w}$ \\
\hline j & $=$ & dh & 。 & 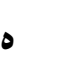 & $=$ & $\mathbf{h}$ \\
\hline J & $=$ & $\mathbf{r}$ & & $\varepsilon$ & $=$ & , \\
\hline j & $=$ & $\mathrm{z}$ & & ي & $=$ & $\mathbf{y}$ \\
\hline س & $=$ & $\mathrm{s}$ & & & & \\
\hline 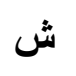 & $=$ & sh & \multicolumn{4}{|c|}{ Untuk Madd dan Diftong } \\
\hline ص & $=$ & ș & $i=$ & $=$ & \multicolumn{2}{|c|}{$\bar{a}$ (a panjang) } \\
\hline 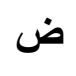 & $=$ & d & 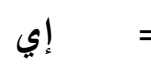 & $=$ & \multicolumn{2}{|c|}{$\overline{1}$ (i panjang) } \\
\hline b & $=$ & $t$ & 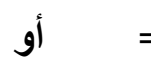 & $=$ & \multicolumn{2}{|c|}{$\bar{u}$ (u panjang) } \\
\hline ظ & $=$ & $z$ & او او & $=$ & \multicolumn{2}{|c|}{ aw } \\
\hline$\varepsilon$ & $=$ & 6 & أي اي & $=$ & \multicolumn{2}{|l|}{ ay } \\
\hline
\end{tabular}

Contoh penulisan dengan transliterasi:

اعوذ بالله من الشيطان الرجيم (a'üdhu bi al-Lāh min al-shaytān al-rajim);

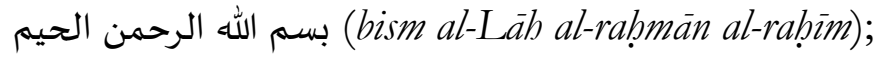

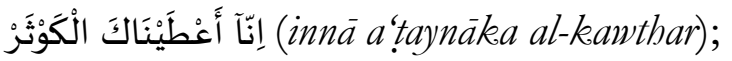

(fasalli lirabbika wanhar);

صباح الخير (șabāh al-khayr). 


\title{
INDUKTIVISME SEBAGAI BASIS PENGEMBANGAN ILMU PENGETAHUAN DALAM ISLAM
}

\author{
Masdar Hilmy \\ (Pascasarjana IAIN Sunan Ampel Surabaya \\ Email: masdar.hilmy@gmail.com)
}

Abstract: This paper analyses how inductive paradigm bas been misperceived and mistreated by Muslims, and discusses the extent to which the inductive paradigm and the deductive one has long been competing to one another throughout the development of science in Islam. This paper argues that the backwardness of Muslim civilization is due to the fact that the inductive paradigm has long been neglected and has been misperceived by Muslim scientists as a Western type entity which should be deconstructed and, therefore, should be put aside. This attitude stems from the Muslims' attitude towards the Qur'an and Hadith as direct sources of modern science, scientific corpuses from which modern theories of sciences emanate. In order to achieve an advancement of science, Muslims do not have any choice other than treating the inductive paradigm properly as an epistemological as well as methodological apparatus in developing sciences either natural sciences, social humanities and religious as well as Islamic studies.

Abstrak: Makalah ini menganalisis bagaimana paradigma induktif telah dianggap dan diperlakukan salah oleh umat Islam, dan membahas sejauh mana paradigma induk.tif dan deduktif telah lama bersaing satu sama lain dalam kancah perkembangan ilmu pengetahuan dalam Islam. Penulis berpendapat bahwa keterbelakangan peradaban Muslim dikarenakan paradigma induktif telah diabaikan oleh para ilmuwan Muslim, dan dipahami salah sebagai milik-Barat yang harus didekonstruksi dan dikesampingkan. Sikap ini berasal dari sikap umat Islam yang memperlakukan al-Qur'an dan hadis sebagai dua sumber ilmu, corpus ilmiah sumber teori-teori modern dalam ilmu. Demi kemajuan ilmu pengetahuan, umat Islam tidak punya pilihan lain selain memperlakukan paradigma induktif secara benar sebagai alat epistemologis sekaligus metodologis dalam mengembangkan sains dalam komunitas Muslim baike ilmu alam, sosial humaniora maupun studi agama serta studi Islam.

Keywords: induktif, deduktif, paradigma, sains, al-Qur'an, hadis. 
SUDAH jamak dimaklumi bahwa Islam adalah agama yang sangat mendorong pada pencarian dan penguasaan ilmu pengetahuan. Tidak perlu dijelaskan di sini berapa jumlah ayat al-Qur'an dan hadis Nabi yang menganjurkan pentingnya menuntut ilmu. ${ }^{1}$ Bahkan wahyu pertama yang diturunkan oleh Allah kepada Nabi Muhammad Saw. adalah perintah untuk membaca (iqra'), sebuah aktivitas yang secara literal bermakna proses kognisi melalui pengujaran-pengujaran verbal atas apa yang tertulis secara fisik. Hal ini berbeda dengan kata "membaca" dalam artian melafalkan (to recite, tala-yatlu-tilawah) secara verbal yang dilakukan tanpa sebuah kesadaran kognitif.

Pertanyaan generik yang patut direfleksikan adalah, mengapa dalam penguasaan ilmu pengetahuan dan teknologi umat Islam menjadi kalah dibandingkan dengan umat-umat atau peradaban lain di luar Islam? Mengapa Abad Pencerahan lahir dari rahim peradaban Barat-Eropa, dan bukan dari Islam? Memang betul bahwa Islam pernah menguasai jagat ilmu pengetahuan sebelum Barat melakukannya hingga saat ini. Juga benar belaka bahwa kejayaan Barat tidak bisa dilepaskan dari peran Islam sebelum masa kejatuhannya. Tetapi hal ini tidak dapat dijadikan apologi buta yang secara terus-menerus dijadikan sebagai self-defense mechanism untuk menutupi kelemahan kita. Daripada melakukan apologi, sebaiknya kita melakukan otokritik dan refleksi internal untuk mengevaluasi apa yang salah dalam pengembangan ilmu pengetahuan dan teknologi sehingga umat Islam tidak kalah dalam bersaing dengan dunia lain.

Kertas kerja ini hendak mengulas secara ringkas bagaimana Islam, melalui kedua sumber sucinya-al-Qur'an dan hadismemberikan inspirasi bagi pengembangan ilmu pengetahuan dan teknologi sebagai sebuah proses induktif melalui alat bantu seperangkat metodologi ilmiah yang dapat dipertanggungjawabkan. Islam, melalui kedua teks suci di atas, tidak saja mendorong dikuasainya ilmu-ilmu pengetahuan

${ }^{1}$ Menurut catatan Abdus Salam, terdapat sekitar 750 ayat al-Qur'an yang mendorong kaum beriman mempelajari dan menelaah alam semesta beserta isinya. Jumlah ini setara dengan seperdelapan isi al-Qur'an secara keseluruhan. Baca, Muhammad Abdus Salam, Renaissance of Sciences in Islamic Countries (Singapore: World Scientific Publishing, 1994), 95. 
normatif yang pembuktian kebenarannya hanya bisa dilakukan secara apriori, tetapi juga menginspirasi dikembangkannya cara berpikir induktif yang pembuktian kebenarannya dilakukan secara aposteriori.

\section{Reposisi Teks Suci}

Selama ini al-Qur'an dan hadis diposisikan oleh umat Islam sebagai sumber dari pengembangan ilmu pengetahuan dan teknologi. Hal yang demikian adalah benar belaka dan seharusnya memang demikian. Tetapi, tidak sedikit dari umat Islam salah memahami proposisi "Al-Qur'an dan hadis sebagai sumber" dengan mengatakan bahwa: pertama, seluruh kandungan dalam keduanya adalah ilmiah dan tidak bertentangan dengan prinsip-prinsip ilmu pengetahuan dan teknologi; kedua, ilmu pengetahuan apapun yang dikembangkan umat manusia telah ada dalam kedua sumber Islam tersebut. Oleh karena itu, keduanya dapat dijadikan sumber rujukan langsung dalam upaya pengembangan jenis ilmu apapun di dunia ini, baik yang eksakta maupun ilmu-ilmu sosial-humaniora. Artinya, ilmu apapun dianggap sudah ada dalam al-Qur'an maupun hadis.

Kedua anggapan di atas sudah barang tentu sarat dengan muatan apologetik dan ideologis yang justru menggerus semangat dan prinsip-prinsip ilmiah itu sendiri. Memang betul bahwa terdapat sejumlah ayat dalam al-Qur'an yang barangkali sejalan dengan salah satu satau beberapa teori modern sains. Namun demikian, menganggap bahwa al-Qur'an merupakan sumber langsung bagi teori-teori sains modern merupakan anggapan yang simplistik dan bahkan mengandung kesalahan fatal. Betapapun keduanya tidak dapat disejajarkan. Oleh karena itu, menganggap keduanya sejajar berarti merendahkan al-Qur'an dan menuhankan sains. Al-Qur'an bukanlah kitab sains. Bahwa al-Qur'an dan hadis menginspirasi pengembangan sains memang benar adanya. Tetapi bahwa al-Qur'an dan sains memiliki posisi sejajar karena sama-sama mengandung kebenaran ilmiah merupakan sebuah reduksi berpikir yang simplistik dan tidak bernilai akademik-ilmiah.

Harus diakui, memang betul ada banyak fenomena alam yang-secara kebetulan atau tidak-dapat dijelaskan melalui 
sejumlah ayat al-Qur'an. Teori heliosentrisme, misalnya, memang sejalan dengan Surat Yasin (36:38). ${ }^{2}$ Sebagai sebuah ikhtiar intelektual (intellectual effort), maka upaya mengaitkan antara sains dan al-Qur'an—atau 'ayatisasi' sains-adalah sahsah saja. Namun yang perlu dicermati secara kritis di sini adalah bahwa al-Qur'an bukanlah kitab sains. Keduanya memiliki paradigma dan prosedur pembenaran yang berbeda. Perlu dicermati secara kritis, misalnya, apakah betul kata-kata 'tajri' memang bermakna 'berputar' dan "mustaqarrun" bermakna 'poros'. Apakah betul bahwa 'tajri di sini bermakna berputar dalam pengertian berputar di tempat, tidak berpindah-pindah. Ataukah ia justru bermakna berputar tetapi bergerak melingkar dalam sebuah gerakan orbital. Kedua, apakah betul bahwa 'mustaqarrun' di sini bermakna poros atau as dalam posisi diam? Ataukah ia bermakna tempat beredar dalam pengertian lingkaran orbital?

Sikap mempersamakan antara kitab suci dan sains modern lebih dikenal sebagai Bucaillisme, merujuk pada seorang ilmuwan Perancis, Maurice Bucaille, yang memilih masuk Islam setelah mengkaji secara serius kandungan ilmiah dalam alQur'an. ${ }^{3}$ Dia terkagum-kagum dengan muatan kitab suci tersebut yang dianggapnya sangat relevan dengan temuantemuan teoretik ilmiah abad modern, seperti teori heliosentrisme, teori penciptaan manusia dan penciptaan alam dan semacamnya. Karya Bucaille bahkan telah menginspirasi banyak ilmuwan Muslim untuk menggali khasanah ilmu pengetahuan saintifik dalam al-Qur'an dan menganalisis kandungannya dengan menggunakan teori-teori saintifik modern. ${ }^{4}$

2Lihat, misalnya, John Walbridge, God and Logic in Islam: The Caliphate of Reason (Cambridge: Cambridge University Press, 2011), 12.

${ }^{3}$ Dia menulis sebuah buku monumental dalam bahas Perancis yang brjudul La Bible le Coran et la Science yang kemudian diterjemahkan ke dalam bahasa Inggris oleh Alastair D. Pannel and penulisnya berjudul The Bible, the Qur'an and Science (Tripoli: Islamic Call Society, 1976).

${ }^{4}$ Baca, misalnya, Nadiah Thayyarah, Buku Pintar Sains dalam al-Qur'an (Jakarta: Zaman, 2013) yang diterjemahkan dari bahasa Arab berjudul Mausu'ah al-I'jaz al-Qur'ani, terbitan Dar al-Yamama, Abu Dhabi. Juga, periksa Zaghlul An-Najjar, Sains dalam Hadis: Mengungkap Fakta Ilmiah dari 
Perlakuan terhadap al-Qur'an dan hadis sebagai kitab ilmiah dan sumber bagi ilmu-ilmu modern tidak selamanya menguntungkan, tetapi-dalam derajat tertentu-bisa saja merugikan. Hal ini karena al-Qur'an dan sains dibangun di atas fondasi epistemologis yang berbeda. Jika al-Qur'an merupakan produk kalam Allah yang diwahyukan secara deduktif, maka sains merupakan hasil olah pikir manusia yang dilakukan secara induktif. Kedua, sains selalu tunduk dan terbuka pada falsifikasi ilmiah yang dilakukan oleh para ilmuwan, sedangkan al-Qur'an tidak. Oleh karena itu, yang diperlukan bagi umat Muslim terhadap al-Qur'an adalah mengimani isinya secara totalitas, bukan menguji kebenarannya secara induktif karena bisa saja bertentangan dengan temuan-temuan sains modern. Selain itu, sains memiliki durabilitas atau rentang waktu kebenaran, sementara al-Qur'an bersifat mutlak dan abadi.

Bahwa terdapat sebagian-besar ataupun kecil-kandungan al-Qur'an yang dapat dijelaskan melalui teori sains modern memang sebuah hal yang wajar belaka. Tetapi menganggap bahwa seluruh isi kandungan al-Qur'an dapat dijelaskan melalui teori-teori sains merupakan sebuah "kegenitan ilmiah" yang tidak akan berdampak apa-apa bagi kemuliaan al-Qur'an. Ada banyak bagian dalam al-Qur'an yang keberadaannya merupakan misteri yang tidak mudah dipecahkan oleh rumus-rumus sains modern. Salah satu kandungan dalam al-Qur'an yang tidak mudah untuk dijelaskan melalui teori sains modern adalah dimensi eskatologis seperti rukun iman, fenomena kematian, alam kubur dan siksa kubur, surga dan neraka, dan eksistensi Tuhan itu sendiri.

Jikapun pengompromian antara al-Qur'an dan sains dipaksakan, maka yang terjadi adalah sebuah "kebuntuan paradigmatik" (paradigmatic cul-de-sac). Pengompromian keduanya secara paksa justru akan melahirkan anarkisme paradigmatik yang justru dapat mengerdilkan perkembangan masing-masing. Bagaimanapun juga, perkembangan sains akan tetap diwarnai dengan penggunaan metode induksi ketimbang deduksi.

Kemukjizatan Hadis Nabi (Jakarta: Amzah, 2011), yang diterjemahkan dari bahasa Arab berjudul Al-I'jaz al-'Tlmiy fi al-Sunnab al-Nabawiyyah, terbitan Nahḍah Miṣr li al-Ṭiba'ah wa al-Nashr wa al-Tauzi. 
Kebenarannya bersifat empiris, hipotetis dan verifikatif (empiricobipotetiko-verifikatif). Penerapan prinsip-prinsip ilmiah seperti ini jelas tidak terlalu relevan untuk diterapkan dalam mendekati alQur'an, sebab pembuktian kebenarannya bersifat normatifdogmatis-transendental. Oleh karena itu, diibaratkan sebagai rel kembar (double-track), biarlah masing-masing berjalan sesuai dengan prinsip dan paradigmanya sendiri-sendiri yang tidak saling mengintervensi dan menghegemoni satu sama lain. Yang diperlukan adalah etos menghargai di kalangan ilmuwan terhadap preposisi-preposisi teoretik yang dikemukakan oleh masing-masing.

Perlakuan kitab suci sebagai sumber kebenaran ilmu pengetahuan bisa mengganggu dan mengintervensi proses scientific inquiry yang dilakukan oleh ilmu pengetahuan itu sendiri. Mestinya kitab suci cukup diperlakukan sebagai sumber inspirasi, bukan sumber kebenaran ilmu pengetahuan yang bersifat verbatim. Semangat menjunjung tinggi pencarian obyektifitas ilmiah bisa terganggu karena eksistensi teks suci akan membayangi setiap jengkal proses inquiry dimaksud. Hal ini akan berakibat pada pemutlakan preposisi-preposisi ilmiah yang diangkat oleh para ilmuwan dari hamparan data yang berserak.

Sekali teks suci diangkat sebagai sumber-dari segala sumber kebenaran ilmiah, maka ia akan membayangi ke manapun pengembangan sains akan diarahkan. Dalam konteks ini, apa yang disebut sebagai takdis al-afkar al-ilmi bisa saja terjadi akibat kemenyatuan antara sains dan kitab suci. Yang lebih fatal lagi adalah, kitab suci tidak akan mampu melakukan pembelaan diri ketika teori-teori ilmiah yang dihasilkan para ilmuwan terbukti tidak valid dan, oleh karena itu, tidak berlaku kembali akibat terdapatnya teori pengganti yang jauh lebih valid. Hal ini bisa terjadi karena watak dasar sains adalah terbukanya kemungkinan bagi para ilmuwan untuk menguji validitas sebuah teori secara terus-menerus. Jika dalam tradisi ilmiah sebuah teori dapat dianggap out of date (kadauwarsa) karena ada teori-teori pengganti yang lebih valid, maka tidak demikian dengan teks suci. Kebenaran teks suci haruslah ditempatkan secara proporsional bukan dalam perspektif ilmiah teoretik, melainkan sebagai 
sebuah kitab inspirasi bagi umat Muslim dalam pencarian ilmiah yang tiada henti. ${ }^{5}$

\section{Induktivisme; Tradisi yang Terlupakan}

Dalam tradisi kesarjanaan Islam, terdapat dua paradigma keilmuan yang berkembang dan menjadi basis bagi pengembangan dunia ilmu; paradigma deduktif dan paradigma induktif. Paradigma deduktif merujuk pada penggunaan logika Aristotelian dalam memproduksi sebuah kebenaran. Kehadirannya telah berjasa dalam melahirkan sebagian besar ilmu-ilmu keagamaan seperti ilmu-ilmu tafsir, ilmu-ilmu hadis, ilmu fiqih, ilmu mantiq, ilmu balaghah, tata bahasa Arab, dan sebagainya. ${ }^{6}$ Dalam ilmu eksakta, matematika merupakan bidang keilmuan yang paling banyak menggunakan paradigm deduktif. Kebenaran ilmu-ilmu deduktif hanya bisa dibuktikan secara logika yang lebih bersifat apriori dan normatif. ${ }^{7}$

Penggunaan paradigma deduktif dalam tradisi kesarjanaan Muslim sedikit banyak dipengaruhi oleh tradisi kesarjanaan Yunani. ${ }^{8}$ Aristoteles (384-322 SM), misalnya, telah menuliskan sebuah motto dalam akademinya: "Barang siapa yang tidak mengetahui matematika jangan mengikuti akademi ini". Plato (428-348 SM), guru Aristoteles, memiliki pengalaman buruk dengan pengetahuan sensoris. Menurutnya, pengetahuan apapun yang berasal dari dunia penginderaan tidak memiliki nilai filosofis serta memiliki signifikansi ilmiah yang hanya muncul dari dunia gagasan atau alam pikiran manusia. ${ }^{9}$

Segala jenis ilmu pengetahuan yang berbasis pada paradigma deduktif telah tumbuh dan berkembang dengan pesat di dunia Islam salah satunya karena upaya penerjemahan karya-karya Yunani kuno pada masa dinasti Abbsiyah. Pada masa khalifah al-

${ }^{5}$ Farzin Deravi, "Scientific Method and the Quest for Objective Knowledge", dalam Rais Ahmad, Islam and Scientific Debate: Searcbing for Legitimacy (New Delhi: Global Vision Publishing House, 2006), 117.

'Lihat, Joep Lameer, Al-Farabi \& Aristotelian Syllogistics: Greek Theory \& Islamic Practice (Leiden: E.J. Brill, 1994), 211-12.

${ }^{7} I b i d ., 212$.

${ }^{8}$ Ibid., 42.

${ }^{9}$ C.A. Qadir, Philosophy and Science in the Islamic World (London: Routledge, 1988), 18. 
Ma'mun, didirikanlah sebuah pusat penerjemahan yang diberi nama Bayt al-Hikmah (yang secara literal bermakna rumah kebijaksanaan). Di lembaga inilah hamper seluruh karya filsafat dan kedokteran Yunani diterjemahkan. Sejumlah ilmuwan Muslim dan penerjemah kenamaan bekerja di lembaga ini dan digaji sangat layak oleh Negara, di antaranya adalah Hunayn ibn Isḥaq dan putranya Isḥaq ibn Hunayn, al-Khawarizmi, al-Rāzi, dan al-Kindi. Di lembaga ini pulalah para matematikawan dari Arab dan India bekerjasama untuk menghasilkan sistem penomoran Arab sebagaimana diadopsi matematika modern hingga saat ini. ${ }^{10}$

Sekalipun banyak karya ilmiah Yunani diterjemahkan ke dalam bahasa Arab dan menjadi inspirasi penting bagi dunia Muslim, bukan berarti bahwa jenis ilmu pengetahuan Islam merupakan replika semata dari ilmu pengetahuan Yunani. Sebelum masa Islam, dapat dikatakan keseluruhan body of science terdiri dari susunan teori yang bersifat deduktif. Bahkan ilmu pengetahuan Yunani dikembangkan atas dasar hipotesis dan pendapat reflektif. Adalah para ilmuwan Muslim yang pertama kali memperkenalkan dan menggunakan metode induktif secara ekstensif. Kenyataan ini diakui dengan baik oleh P.K. Hitti, William Smith, George Sarton, John Herman Randell dan masih banyak lagi lainnya. ${ }^{11}$ Para ilmuwan Yunani seperti Plato, Aristoteles, Archimedes, Pythagoras dan lainnya sangat menggemari permainan logika yang menjadi basis bagi ilmu-ilmu deduktif. Oleh karena itu, mereka tidak menggunakan laboratorium sebagai media pengembangan ilmu pengetahuan.

Sementara itu, paradigma induktif berangkat dari nalar empiris melalui sejumlah perangkat metodologis seperti eksperimen, observasi dan penginderaan secara umum. Dalam tradisi kesarjanaan Islam, eksperimen dan observasi ini lebih banyak digunakan dalam ilmu-ilmu eksakta seperti ilmu falak (astronomi), geodesi, metalurgi, optik dan kedokteran. Paradigma induktif lebih banyak mengandalkan kekuatan argumentasi aposteriori atas pengamatan terhadap apapun yang

${ }^{10}$ Sa'id al-Andalusi, Science in the Medieval World: "Book of the Categories of Nations (Austin, Texas: The University of Texas Press, 1991), 99.

${ }^{11}$ C.A. Qadir, Philosopby and Science, 110. 
terjadi atau dialami. Pada periode belakangan menjelang Abad Pencerahan, paradigma induktif mulai masuk ke dalam jagat ilmu pengetahuan Barat setelah Francis Bacon (1561-1626) memperkenalkan apa yang ia sebut sebagai "novum organum", yakni sebuah instrumen inquiry baru untuk menggantikan instrumen ilmiah yang berbasis pada kekuatan nalar Aristotelian.

Sir Muhammad Iqbal dalam karya monumentalnya yang sudah menjadi klasik, The Reconstruction of Religious Thought in Islam, menegaskan bahwa Islam memberikan ruang yang sangat luas bagi semangat induktif dalam proses pencarian kebenaran ilmiah. Menurut dia, "the birth of Islam is the birth of inductive intellect" (kelahiran Islam adalah kelahiran nalar induktif). ${ }^{12}$ Dilihat secara sekilas, pernyataan ini terkesan apologetik terutama ketika prestasi peradaban Islam tengah berada dalam titik nadir. Namun kenyataannya adalah bahwa sejarah Eropa sejak zaman Yunani sampai awal abad ke-17 merupakan cerita tentang absennya eksperimentasi dan observeasi di satu sisi, dan pemberhalaan pemikiran dan penalaran reflektif di sisi lain. ${ }^{13}$ Nalar deduktif, sekalipun sangat bermanfaat di tahap-tahap awal peradaban manusia, terbukti menjadi kendala bagi pengembangan ilmu-ilmu fisika yang sangat mengandalkan kedua instrumen ilmiah tersebut.

Seorang ilmuwan Barat, Briffault, dalam bukunya The Making of Humanity — sebagaimana dikutip oleh Iqbal-mengakui bahwa:

Neither Roger Bacon nor bis later name sake has any claim to be credited with having introduced the experimental method. Roger Bacon was no more than one of the apostles of Muslim science and method to Christian Europe... The experimental method of Arabs was by Bacon's time wide-spread and eagerly cultivated throughout Europe. ${ }^{14}$

Kutipan tersebut secara jujur menolak anggapan bahwa Roger Bacon merupakan perintis metode induktif dalam pengembangan ilmu pengetahuan. Briffault bahkan secara terang-terangan menegaskan bahwa Bacon adalah tidak lebih sebagai seorang murid dari para ilmuwan Muslim yang pada zamannya penggunaan eksperimen sangat popular.

${ }^{12}$ Sir Muhammad Iqbal, The Reconstruction of Religious Thought in Islam (Stanford, California: Stanford University Press, 2013), 101.

${ }^{13}$ Qadir, Philosophy and Science, 18.

${ }^{14}$ Iqbal, The Reconstruction, 200. 
Di sisi lain, para ilmuwan Muslim tidak semata-mata menggandalkan metode deduktif dalam proses ilmiahnya, tetapi juga metode induktif. Menurut Qadir, para ilmuwan Muslim bahkan tidak mau menerima hasil penelitian ilmiah sebelum mereka membuktikannya dalam ruang-ruang laboratorium. Jabir Ibn Hayyan, misalnya, mempunyai sebuah laboratorium sendiri di mana dia menyiapkan berbagai bahan kimia untuk serangkaian uji coba. Demikian pula sejumlah ilmuwan Muslim lain seperti al-Biruni, Umar Khayyam, Ibnu Sina, Ibnu Yunus, al-Tusi, alKhawarizmi, kesemuanya memiliki laboratorium atau bekerja di dalamnya. Hasil-hasil penelitian mereka selalu didasarkan pada uji laboratorium, bukan semata hasil penalaran intelektualreflektif.

Dalam konteks penggunaan metode induktif, Saleh Iskandar Poeradisastra (1981) sebagaimana diamini oleh Jujun S. Suriasumantri menegaskan bahwa salah satu faktor yang membuat sains dan teknologi berkembang pesat pada masa keemasan Islam adalah berkat metode eksperimen yang digalakkan oleh para sarjana Muslim yang mencapai kulminasinya pada abad ke 9 hingga 12 M. ${ }^{15}$ Semangat mencari kebenaran yang diinisiasi oleh para pemikir Yunani dan hampir padam dengan jatuhnya Kekaisaran Romawi dihidupkan kembali pada masa peradaban Islam.

Kenyataan kontribusi Islam terhadap pengembangan semangat ilmiah juga diakui oleh para sarjana Barat. H.G. Wells, misalnya, pernah menegaskan bahwa "Jika orang Yunani adalah bapak metode ilmiah, maka orang Muslim adalah bapak angkatnya". ${ }^{16}$ Dalam perjanalan sejarahnya, lewat peradaban Muslimlah, dan bukan lewat peradaban Latin, dunia modern sekarang ini mendapatkan kekuatan dan cahayanya. Pengakuan yang sama juga datang dari seorang ilmuwan kontemporer, George Saliba, yang menegaskan bahwa "para ilmuwan Abad Pencerahan lebih banyak merujuk pada dunia Islam ketimbang sumber-sumber Yunani kuno dalam melakukan aktivitas

15Jujun S. Suriasumantri, Filsafat Ilmu: Sebuah Pengantar Populer (Jakarta: Pustaka Sinar Harapan, 2005), 113.

${ }^{16}$ H.G. Wells, The Outline of History: Being a Plain History of Life and Mankind (New York: P.F. Collier \& Son Company, 1951), 624. 
ilmiahnya, terutama terkait dengan ilmu-ilmu empiris seperti astronomi dan kedokteran. Kenyataannya, hampir tidak ada teori astronomi pada Abad Pencerahan yang merujuk langsung pada sumber-sumber Yunani klasik."17

Metode eksperimen ini dimulai oleh ahli-ahli kimia Muslim yang pertama kali didorong oleh motivasi mendapatkan "obat ajaib" untuk tetap awet muda (elixir vitae) dan rumus membuat emas dari logam biasa, namun lambat laun berkembang menjadi metode berpikir ilmiah. Pendek kata, metode eksperimen secara konseptual ditemukan dan dikembangkan oleh para pemikir Muslim tetapi secara sosiologis dipopulerkan oleh Francis Bacon (1561-1626 M). Kata Bacon dalam The Advancement of Learning, "ketika akar-akar filsafat mengalami krisis pengalaman, maka ia menjadi sesuatu yang mati". Ketika dia mengutuk Plato dan Aristoteles atas metode filsafat spekulatif yang mereka pergunakan, Bacon menegaskan bahwa "Kebenaran bukanlah, sebagaimana yang dipikirkan Plato, penghuni akal asli, ia datang dari luar, melalui observasi dan eksperimen". ${ }^{18}$

Dalam konteks ini, menarik untuk dicatat bahwasannya seorang teolog anti-Aristotelian, Ibn Taymiyyah (1263-1328) dalam risalahnya, al-Radd 'ala al-Mantiqiyyin (Sanggahan terhadap para Ahli Mantiq), melancarkan serangan yang keras atas logika Aristotelian, mengkritisi teori-teorinya tentang definisi, penghakiman (judgment) dan silogisme, sekaligus memuluskan jalan bagi penggunaan metode induktif. Tujuan Ibn Taymiyyah adalah untuk menunjukkan bahwa instrumen (logika) yang digunakan oleh para filosof mengandung kelemahan. ${ }^{19}$ Salah satu ungkapannya yang sangat terkenal, "al-baqiqah fi al-a'yan la fi al-adzhban", persis memberikan semangat bagi penggunaan metode induktif dalam pencarian kebenaran.

\section{Fundamental Paradigma Induktif}

Induktivisme dapat didefinisikan baik sebagai sebuah proses maupun sebagai sebuah instrumen. Sebagai sebuah proses,

${ }^{17}$ George Saliba, Islamic Science and the making of the European Renaissance (Cambridge \& London: The MIT Press, 2007), 231.

18Sebagaimana dikutip dalam Qadir, Philosophy and Science, 127.

${ }^{19}$ Qadir, Philosophy and Science, 128, 136. 
induktivisme bisa bermakna dua hal. Pertama, induktivisme merujuk pada proses berpikir dari sesuatu yang khusus menuju yang umum. Misalnya: Ahmad pasti mati-Ahmad adalah manusia-semua manusia pasti mati. ${ }^{20}$ Kedua, dalam konteks penelitian ilmiah, maka induktivisme adalah proses memperoleh ilmu pengetahuan melalui aktivitas riil yang kebenarannya dibuktikan melalui uji material secara empiris, baik di laboratorium maupun di alam nyata. Proses ilmiah dalam penelitian induktif tidak berawal dari sebuah teori umum, melainkan dari data lapangan yang kemudian direfleksikan oleh peneliti menuju sebuah teori umum. ${ }^{21}$

Fundamental metode induktif pada intinya bertumpu pada paradigma Cartesian yang menelisik dan mengurai realitas kehidupan berdasar hukum sebab-akibat. Paradigma ini dinisbatkan kepada Rene Descartes, seorang filosof besar Perancis yang ikut membidani kelahiran peradaban modern Barat. Paradigma ini merupakan representasi dari kemenangan kaum rasionalis dalam panggung ilmu pengetahuan dan hanya tunduk pada bukti-bukti empiris yang mampu menggagalkan tesis kaum rasionalis. ${ }^{22}$ Paradigma ini telah melahirkan kelompok rasionalis atau mazhab rasionalisme dalam sejarah ilmu pengetahuan dan filsafat yang berpijak pada prinsip-prinsip logika matematika formal. Pada awalnya paradigma ini berjalan secara deduktif sebagai buah dari dominasi tradisi metode deduktif-Aristotelian. Mazhab ini berpijak pada sebuah adagium yang sangat masyhur: cogito ergo sum/I think therefore I am (saya berpikir saya ada). Pada perkembangannya, paradigma Cartesian memantik antithesis dari kalangan empiris yang mendasarkan

${ }^{20}$ Evan Heit, "What Is Induction and Why Study It?", dalam Aidan Feeney \& Evan Heit (eds.), Inductive Reasoning: Experimental, Developmental and Computational Approaches (Cambridge: Cambridge University Press, 2007), 124.

${ }^{21}$ Rafael J. Engel \& Russell K. Schutt, Fundamentals of Social Work Research (California \& New Delhi: Sage Publication, 2010), 34.

${ }^{22}$ Richard A. Watson, The Breakdown of Cartesian Metaphysics (Cambridge, MA: Hackett Publishing, 1987), 7. 
kebenaran segala sesuatu pada kehadiran fakta dan realitas di dalam kehidupan nyata. ${ }^{23}$

Di awal-awal sejarah sains dalam Islam, observasi dan eksperimen merupakan dua hal yang tidak terpisahkan. Sebagaimana catatan Muammar Dizer, warisan intelektual Islam ditunjukkan oleh sejumlah institusi penting untuk pengembangan sains seperti rumah sakit, sekolah (madrasah), perpustakaan umum dan observatorium. ${ }^{24}$ Yang tersebut terakhir merupakan institusi yang mereprsentasikan tradisi penelitian saintifik tingkat tinggi berdasarkan pada observasi yang sistematis dan hati-hati. Ia juga menggambarkan bidang kajian tentang karya-karya ilmiah kuantitatif. Ia terdiri dari kerja tim di kalangan para ilmuwan. Tidak diragukan lagi bahwa observatorium, sebagai sebuah institusi ilmiah, sangat berhutang budi pada Islam.

Bukti-bukti awal mengenai penggunaan observasi dalam tradisi intelektual Islam dapat ditemukan, misalnya, dalam literatur periode dinasti Umayyah (661-750). Dreyer menegaskan bahwa para khalifah dinasti Umayyah mempunyai sebuah observatorium dekat Damaskus. ${ }^{25}$ Tetapi menurut Pushmann, khalifah Mu'awiyah (661-680) telah mendirikan sejumlah observatorium di kota tersebut. ${ }^{26}$ Pernyataan-pernyataan semacam ini, menurut al-Hassan, sudah barang tentu tidak didasarkan pada sumber-sumber yang dapat dipercaya dan eksistensi observatorium ini belum memungkinkan didirikan pada masa-masa itu karena aktivitas ilmiah dalam Islam belum begitu berkembang yang berakibat pada pembangunan observatorium. ${ }^{27}$ Tetapi catatan paling awal tentang observasi

${ }^{23}$ Lebih jauh tentang pertentangan di antara keduanya, baca, misalnya, Erhard Scheibe, Between Rationalism and Empiricism: Selected Papers in the Philosophy of Physics (Berlin: Springer-Verlag, 2001).

${ }^{24}$ Muammar Dizer, "Observatories and Astronomical Instruments," dalam A.Y. al-Hassan (ed.), Science and Technology in Islam (Paris \& Beirut: UNESCO Publishing, 2001), 236.

25John Luis Emil Dreyer, History of Astronomy from Thales to Kepler (New York: Dover Publications, 1953), pp. 245-246.

26Pushmann, sebagaimana dikutip Dizer, "Observatories and Astronomical Instruments," 236.

27Dizer, "Observatories and Astronomical Instruments," 236. 
astronomi di dunia Islam merujuk pada $184 \mathrm{H} / 800 \mathrm{M}$. Ahmad alNihawandi mengobservasi pergerakan matahari di Jundishapur di Persia untuk kompilasinya yang berjudul al-Zij al-mushtamil (Tabel komprehensif). Dalam konteks ini, Sayli menyatakan bahwa dia tidak mampu memperoleh ilmu apapun terkait dengan instrumen al-Nihawandi tersebut. ${ }^{28}$ Sekalipun karya astronomi tentang alam milik al-Nihawandi biasanya membutuhkan kerjasama beberapa orang, Sayli tidak menyediakan informasi apapun tentang aspek ini dari aktivitasnya.

Menurut banyak sumber yang dapat dipercaya, tradisi observasi astronomis yang lebih sistematis dalam Islam dimulai pada dinasti Abbasiyah, tepatnya pada zaman khalifah alMa'mun. Observasi ini dilakukan di bawah pengawasan di alunalun Shammasiyya di Baghdad dan di padepokan Dayr Murran di gunung Qasiyun di Damaskus. ${ }^{29}$ Aktivitas yang dikerjakan di dua observatorium ini tidak dilakukan secara berkesinambungan tetapi secara mandiri (Baghdad, 213-214H/828-829M; Damaskus, 216-217H/831-832M), sekalipun kita memiliki sebuah referensi tentang perbandingan dua observasi ini tentang equinox musim gugur dibuat di kedua kota tersebut, dan agaknya jelas bahwa kedua kota tersebut memiliki sebuah program observasi yang mirip, sumber-sumber yang ada tidak memberikan informasi yang cukup untuk menjelaskan apakah serangkaian observasi di kedua kota tersebut dilakukan secara layak atau tidak. Selain itu, tidak pula dijelaskan apakah observasi dikerjakan di bangunan yang didesain secara khusus atau tidak, sekalipun sebuah fakta mengatakan bahwa kata pengantar Zij menyebut Yahya b. Abi Mansur (meninggal 215H/830M) yang telah menyebutkan penggunaan "lingkaran" Shammasiyya (da'irat al-Shammasiyya) karena observasi Baghdad menyebabkan orang berpikir tentang sebuah instrumen berukuran besar yang membutuhkan instalasi pasti dan sejumlah ruang tertentu. ${ }^{30}$

${ }^{28}$ Sayli, The Observatory in Islam (Frankfurt: Institute for the History of Arabic-Islamic Science at the Johann Wolfgang Goethe University, 1998), 51.

${ }^{29}$ Dizer, "Observatories and Astronomical Instruments," 237.

${ }^{30} \mathrm{Ibid}$. 


\section{Kreasionisme versus Evolusionisme: Pertarungan Paradigmatik}

Kemunduran Islam dan kejatuhan Baghdad pada tahun 1258 merupakan episode sejarah yang tidak memberikan ruang-ruang yang layak bagi penggunaan paradigma dan metode induktif dalam proses pengembangan ilmu pengetahuan. Sebagai akibat dari terpinggirkannya paradigma induktivisme dalam tradisi keilmuan Islam, maka yang mengemuka dan menominasi jagat ilmiah masyarakat Muslim adalah paradigma deduktif, sebuah tradisi keilmuan yang telah berurat-berakar sejak sebelum Islam. ${ }^{31}$

Secara garis besar paradigma ini dicirikan oleh, pertama, menguatnya normativitas tekstual sebagai sumber dan penghakim akhir dari seluruh rangkaian proses pencarian kebenaran. Kebenaran adalah teks dan teks adalah kebenaran, dalam pengertian harafiyah atau literalnya. Teori-teori sains beserta ukuran kebenarannya tidak boleh keluar dari jalur teks suci. Di sini al-Qur'an dan hadis diperlakukan sebagai scientific corpus yang darinya memancarkan 'mantra-mantra kebenaran' sebagai panduan tunggal dan monolitik dari pengembangan sains dan teknologi dalam Islam. Sebagai akibatnya, proses ilmiah dalam Islam tidak mengenal adanya falsifikasi teks, tetapi falsifikasi teori sains.

Kedua, watak pembenarannya bersifat aksiomatik-tertutup dan tidak memberi ruang bagi munculnya kreasi-kreasi nalar yang berasal dari data lapangan atau pengalaman empiris. ${ }^{32}$ Dalam konteks ini, data lapangan diperlakukan sebagai subordinat dari kebenaran tekstual dan bersifat sekunder. Kebenaran ilmiah yang dimunculkan secara induktif haruslah sejajar dan kongruen dengan ujaran-ujaran literal sebagaimana terdapat dalam kitab suci. Jika terdapat kebenaran ilmiah

${ }^{31}$ Baca, misalnya, Gerhard Endress, "Mathematics and Philosophy in Medieval Islam", dalam Jan P. Hogendijk \& Abdelhamid I. Sabra (eds.), The Enterprise of Science in Islam: New Perspectives (Massachusetts: Massachusetts Institute of Technology, 2003), 121-76.

${ }^{32}$ Mike Oaksford \& Nick Chater, "Commonsense reasoning, Logic, and Human Rationality", dalam Renèe Elio (ed.), Common Sense, Reasoning, and Rationality (Oxford: Oxford University Press, 2002), 189. 
induktif tetapi bertentangan dengan ujaran literal kitab suci, maka keberadaannya tidak diterima sebagai kebenaran ilmiah. Dengan demikian, kebenaran ilmiah-apapun bentuk dan jenisnya-tidak boleh keluar dari ujaran-ujaran tekstual kitab suci tersebut. Jika belum ditemukan penjelasan atas temuantemuan ilmiah sains yang secara kebetulan berlawanan dengan ujaran literal kitab suci, maka sikap maksimal yang bisa dikemukakan oleh ilmuwan Muslim deduktif adalah abstain atau tidak mengambil respon sama sekali atas temuan-temuan tersebut.

Dalam konteks diskursus ilmiah dalam Islam, pertentangan dan kontestasi paradigmatik antara deduktivisme dan induktivisme selalu menyita perhatian ilmuwan Muslim dan seakan tidak pernah tuntas. Salah satu perdebatan klasik dalam jagat ilmu pengetahuan sebagai respresentasi pertarungan di antara keduanya adalah pertarungan antara teori kreasionisme dan evolusionisme. ${ }^{33}$ Teori kreasionisme merujuk pada sebuah keyakinan bahwa asal-usul alam semesta beserta segala isinya merupakan hasil ciptaan Tuhan. Secara ilmiah, teori kreasionisme menganut paradigma deduktif, mengandung diktum-diktum ilmiah yang pembenarannya dilakukan secara apriori-normatif. ${ }^{34}$

Diskursus tentang sains dalam Islam lebih banyak didominasi oleh teori kreasionisme ketimbang evolusionisme atau Darwinisme. Hal ini terjadi karena—sama seperti teori kreasionisme dalam tradisi Kristen-secara tekstual diktum tentang penciptaan alam sebagaimana tertulis di dalam kitab suci, terutama al-Qur'an, mengadopsi prinsip-prinsip penciptaan. al-Qur'an, misalnya, menjelaskan bahwa alam semesta dan seisinya dicptakan oleh Allah dalam waktu enam hari (Qs. 7: 54). Doktrin ini oleh sebagian besar ilmuwan Muslim diperlakukan sebagai the ruling paradigm dalam pengembangan ilmu

${ }^{33}$ Lihat, misalnya, Mahmoud M Ayoub, "Creation or Evolution? The Reception of Darwinism in Modern Arab Thought", dalam Zainal Abidin Bagir (ed.), Science and Religion in a post-Colonial World: Interfaith Perspectives (Adelaide: ATF Press, 2005), 173-190.

${ }^{34}$ Harun Yahya, Why Darwinism is Incompatible with the Qur'an (Istanbul: Global Yayincilik, 2003). 
pengetahuan dan teknologi. Akibatnya, pengembangan ilmu pada prinsipnya tidak boleh berlawanan dengan teori kreasionisme, bahkan selalu bertentangan dengan teori evolusionisme-Darwinisme.

Salah satu figur representasi anti-teori evolusi adalah Harun Yahya, sebuah nama samaran seorang polemisis asal Turki yang bernama Adnan Oktar. ${ }^{35}$ Harun Yahya adalah seorang anti-teori Darwin yang sangat kukuh. Dia berhasil membangun bangunan argumentasi yang cukup meyakinkan tentang kesalahan teori Darwin dan kebenaran teori kreasionisme. Namun demikian, dia tidak berhasil membangun metode ilmiah yang solid di belakang argumen-argumennya itu. Dia menentang segala bentuk materalisme Barat sebagai biang dari seluruh krisis ilmu pengetahuan di Barat yang dapat mengantarkan pada pola hidup materialisme dan ateisme. Dalam membangun argumennya itu, dia lebih banyak menggunakan paradigma deduktif dengan semangat pembenaran atas ayat-ayat al-Qur'an. Oleh karena itu, dia lebih banyak dikenal sebagai seorang apolog yang argumennya lebih banyak bersifat apriori-normatif ketimbang seorang ilmuwan yang argumennya bersifat aposteriori-empiris. ${ }^{36}$

Sementara itu, teori evolusionisme memandang bahwa alam semesta beserta isinya bukan merupakan ciptaan Tuhan, tetapi hasil dari proses evolusi yang panjang. Teori ini berpijak pada teori evolusi Darwin yang pada tahap selanjutnya sering dikenal sebagai Darwinisme. Proses pembuktiannya berjalan secara aposteriori-empiris, mengedepankan bukti-bukti fisik yang ditemukan oleh ilmuwan dalam kehidupan ini. Teori evolusi ini diam-diam diimani dan diikuti oleh sejumlah—kecil—ilmuwan Muslim. Memang mereka kebanyakan tidak berani melakukan perlawanan secara terbuka-karena perlawanan berarti mendelegitimasi kebenaran tekstual ayat-ayat al-Qur'an tentang doktrin penciptaan. Kelompok kecil pendukung teori evolusi ini jelas tidak berani mengambil resiko seberat itu. Keterusterangan akademik dianggap bisa mengancam eksistensi serta reputasi akademiknya, bahkan keselamatan jiwanya. Salah satu

${ }^{35}$ Lihat: www.harunyahya.com.

36Ayoub, "Creation or Evolution?", 189. 
karakteristik ilmuwan evolusionis adalah pandangan-pandangan keagamannya yang sekular, jika bukan ateis.

Salah seorang ilmuwan Muslim yang menganut teori evolusi adalah T.O. Shavanas. Dalam bukunya, Islamic Theory of Evolution: The Missing Link between Darwin and the Origin of Species, dia menegaskan bahwa teori evolusi sangat sejalan dengan Islam. ${ }^{37}$ Buku ini sebenarnya merupakan edisi revisi dari bukunya yang lain, Creation And/orEvolution: An Islamic Perspective. Seluruh gagasan Darwin tentang teori evolusi, menurutnya, tidak bertentangan sama sekali dengan Islam, termasuk gagasan bahwa asal-usul manusia adalah kera. Dia juga menegaskan bahwa semua fisikawan Muslim seperti Ibnu Sina, Ibnu Thufail dan Ibnu Rusyd sebenarnya adalah evolusionis. ${ }^{38}$ Namun demikian, visi evolusionis yang ditunjukkan oleh Shavanas didukung oleh semangat chauvinistiknya untuk mengompromikan antara alQur'an dan sains. Dia, tampaknya, tidak menghendaki jika agama tampil secara 'kikuk' ketika harus berdampingan dengan sains.

Salah seorang evolusionis 'sejati' keturunan Muslim Turkey dan non-Muslim Amerika yang mengaku sebagai ateis, Taner Edis, mengungkapkan pikiran-pikirannya yang anti-kreasionisme melalui bukunya yang cukup kontroversial, An Illusion of Harmony: Science and Religion in Islam. ${ }^{39}$ Dalam buku ini Edis membongkar harmoni antara sains dan agama dalam Islam sebagai sebuah 'mitos.' Menurutnya, apa yang terjadi pada masa kejayaan Islam pada dinasti Abbasiyah bukanlah sains dalam pengertiannya yang modern, tetapi sains dalam pengertiannya pada masa abad pertengahan (medieval) yang memiliki karakter yang jauh berbeda. ${ }^{40}$ Bagi Edis, sains modern bukanlah sains yang diintervensi oleh kekuatan Tuhan untuk menentukan kebenaran ilmiah. Sains sejati, dengan demikian, adalah sains

${ }^{37}$ T.O. Shavanas, Islamic Theory of Evolution: The Missing Link between Darwin and the Origin of Species (London: Brainbow Press, 2010).

${ }^{38}$ T.O. Shavanas, Creation And/or Evolution: An Islamic Perspective (Bloomington, Indiana: Xlibris Corporation, 2005), khususnya Bab 6.

${ }^{39}$ Taner Edis, An Illusion of Harmony: Science and Religion in Islam (New York: Prometheus Books, 2007).

${ }^{40}$ Ibid., 46-47. 
yang tidak lagi direcoki oleh urusan Tuhan atau persoalanpersoalan metafisika lainnya. Inilah yang membuat Edis tidak mau membawa urusan perdebatan tentang Tuhan dalam pembahasannya tentang ilmu pengetahuan modern.

Di luar pertentangan di antara dua kutub di atas, salah satu multiplier effect menguatnya paradigma induktif dalam sains adalah keterpengaruhannya terhadap kajian ilmu-ilmu sosial-humaniora, terutama ilmu-ilmu keagamaan/keislaman. Pertemuannya merepresentasikan percampuran paradigmatik antara deduktivisme dan induktivisme. Jika deduktivisme telah lama 'malang-melintang' dalam jagat ilmu-ilmu keislaman, maka sekarang ini induktivisme mulai merasuk ke dalam kajian tentang ilmu-ilmu keagamaan/keislaman dengan ditandainya kajiankajian yang bersifat empiris.

\section{Paradigma Induktif dalam Ilmu-ilmu Keagamaan/Keislaman}

Harus diakui, peran paradigma induktif selama ini banyak dimainkan dalam pengembangan ilmu-ilmu kealaman seperti fisika, kimia, dan biologi. Selain itu, ada pula ilmu-ilmu lain seperti optik dan astronomi. Sudah jamak dimaklumi bahwa puncak capaian prestasi ilmu pengetahuan dalam Islam pada masa dinasti Abbasiyah adalah berkat peran instrumen metodologis yang bertumpu pada paradigm induktif. Begitu instrumen induktif dimatikan atau tidak dikembangkan secara maksimal, maka pengembangan ilmiah dalam tradisi keilmuan Islam pun mengalami kemunduran. Salah satu alasan mengapa paradigma induktif kurang mendapatkan tempat dalam tradisi keilmuan Islam adalah karena tolok ukur kebenarannya sangat bertumpu pada pembuktian empiris yang berbasis pada data di lapangan. Sebagai akibatnya, pembuktian kebenarannya juga tidak bisa dilepaskan dari peran panca indera dalam mengamati perubahan-perubahan yang terjadi di lapangan.

Kebertumpuan paradigma induktif pada peran penginderaan ilmuwan semacam ini ternyata menjadi titik kuat sekaligus titik lemahnya. Titik kuat karena kebenaran diukur tidak hanya dari kemasukakalan (commonsensicality) sebuah premis ilmiah, tetapi juga pada eksistensi data yang ada dalam kehidupan ini. Dalam 
konteks kriteria dan standar keilmiahan sebuah ilmu pengetahuan, maka prosedur ganda pembuktian kebenaran semacam ini dapat memperkokoh bangunan ontologis dan epistemologis sebuah ilmu pengetahuan. Ilmiah bukan sematamata karena sebuah ilmu itu masuk akal atau rasional, tetapi juga empiris, ada bukti dan fakta-fakta pendukungnya di lapangan (bard facts). Disebut titik lemah karena pembuktian kebenaran yang terlalu bertumpu pada penginderaan tidak bisa dipegangi sebagai sebuah kebenaran hakiki. Dalam perspektif hakikat kebenaran, penginderaan manusia tidak bisa dijadikan sebagai standar bagi sebuah kebenaran. Bahkan, dalam perspektif ilmuilmu keislaman, terutama ilmu tasawuf, panca indera tidak bisa dijadikan sebagai patokan kebenaran karena watak dasarnya yang menipu. ${ }^{41}$

Sebelum membahas bagaimana kaitan antara paradigma induktif dengan ilmu-ilmu keislaman, di sini perlu dijelaskan pula kaitan antara paradigma induktif dengan ilmu-ilmu sosial. Sejak awal berdiri dan perkembangannya, ilmu-ilmu kealaman yang bertumpu pada instrumen induktif mampu melahirkan Abad Pencerahan di Barat dan di dunia Islam. Namun, setelah sekian lama masyarakat ilmuwan mengkaji bagaimana ilmu pengetahuan dan teknologi yang terlahir dari rahim Abad Pencerahan juga problematik di tingkat aksiologis, maka terdapat kecenderungan untuk menimbang kembali standar kebenaran ilmiah pada ilmu pengetahuan. Dalam perkembangan berikutnya, ilmu pengetahuan sebagaimana dikembangkan di Barat dinilai terlalu menitikberatkan pada fakta keras. Sebuah kebenaran disebut benar jika tidak ada pertentangan antara obyek empiris dengan premis-premis teoretik.

Dari sinilah perkembangan ilmu pengetahuan telah tereduksi sedemikian rupa menjadi sebuah politik ilmiah yang berujung pada kompetisi klaim kebenaran antar berbagai mazhab dan kelompok ilmuwan. Di kalangan generasi awal Pencerahan Barat, kebenaran hanya diukur melalui ketersesuaian antara logika atau rasio dengan fakta keras. Tradisi pembuktian semacam ini pada gilirannya melahirkan sebuah tradisi ilmiah

${ }^{41}$ Lihat, misalnya, Abū Ḥamīd al-Gazāli, Ihya 'Ulüm al-Dìn, jilid I (Bayrut: Dār al-Fikr, 1987), 34-5. 
yang disebut positivisme, sebuah istilah yang mengarah pada teori kebenaran ilmiah yang berbasis pada kebenaran obyektif. Tradisi semacam ini banyak berkembang di dalam ilmu-ilmu kealaman (natural sciences), tetapi kehadirannya kurang direspon secara positif oleh ilmu-ilmu social humaniora.

Kebenaran ilmiah, dalam perspektif sosiologi pengetahuan, tidak bisa hanya diukur dengan ketersesuaian antara fakta keras dengan premis-premis teoretik yang sering disebut sebagai kebenaran obyektif. ${ }^{42}$ Menurut kaum konstruktivis, tidak ada sesuatu pun yang disebut sebagai 'kebenaran obyektif. Dalam pandangan mereka, yang ada adalah kebenaran 'obyektif dalam batas-batas subyektifitas individu.' Kebenaran adalah hasil konstruksi manusia atas apa yang dipersepsi melalui kesadaran kognitif dan komonsensikalnya. ${ }^{43}$ Kategori kebenaran ilmiah, dengan demikian, tidak bisa lepas dari kebenaran sosiologis, sebuah kerangka pikir yang menempatkan kolektifitas individu sebagai pembenar dan penghakim akhir bagi sebuah kebenaran.

Dalam perspektif ilmu-ilmu keagamaan dan atau keislaman, penggunaan paradigma induktif jelas menjadi tantangan tersendiri mengingat ilmu-ilmu keagamaan secara genealogis terlahir dari paradigma deduktif. Bahwa kitab suci seperti alQur'an dan Injil, misalnya, mendorong semangat pencarian ilmu pengetahuan melalui paradigma dan perangkat metodologis deduktif itu lain soal. Tetapi bahwa dalam proses pengkajiannya, ilmu-ilmu keagamaan tetap lebih mengedepankan paradigma deduktif sebagai alat untuk menebarkan 'kabar gembira' dan 'misi penyelamatan' terhadap seluruh umat manusia. Hal demikian meniscayakan sebuah pemahaman bahwa eksistensi kitab suci tidak berada dalam posisi untuk dinegosiasikan kebenarannya karena ia mengandung kebenaran aksiomatik yang tidak tunduk pada kebenaran rasional sebagai hasil dari olah pikir manusia. Semangat kebenaran yang terkandung dalam kitab suci dalam tradisi agama apapun tetap sama; kebenaran deduktif.

${ }^{42}$ Werner Stark, The Sociology of Knowledge: Toward a Deeper Understanding of the History of Ideas (New Jersey: Transaction Publications, 1991), 180.

${ }^{43}$ Rob Moore, Towards the Sociology of Truth (London \& New York: Continuum International Publishing Group, 2009), 12. 
Kenyataan di atas menghadapi tantangan lebih serius manakala obyektivitas kebenaran agama dipahami dalam perspektif upaya saintifik. Hal ini karena kriteria kebenaran tidak saja mengadopsi paradigma deduktif, tetapi juga induktif. Perkembangan ilmu alam dan ilmu sosial bahkan lebih banyak mengadopsi paradigma induktif sebagai alat utamanya. Memang benar bahwa paradigma deduktif tetap menempati peran penting dalam pengembangan ilmu pengetahuan, tetapi hanya bisa bekerja pada sub-sub bidang keilmuan tertentu seperti matematika dan silogisme atau logika. Akan tetapi, paradigma dan perangkat metodologis induktif belakangan menjadi perangkat penting yang dapat mengarahkan hitam-putihnya pengembangan ilmu pengetahuan (scientific enterprise). Kenyataan ini semakin menguat manakala tradisi empirisisme dan positivisme Barat melakukan penetrasi dalam diskursus ilmuilmu keagamaan dan atau keislaman. ${ }^{44}$

Bentuk penetrasi empirisisme dan positivisme Barat dapat dilihat, salah satunya, dari bagaimana kajian-kajian keagamaan/keislaman akhir-akhir ini lebih banyak mengambil setting sosial empiris sebagai lokus menjangkarkan berbagai macam analisis teoretik. Tentu saja fenomena ini belum bisa dikatakan bahwa pendulum kajian keagamaan/keislaman sudah bergerak ke arah induktivisme. Hal ini terjadi karena mindset akademik seorang peneliti boleh jadi telah dirasuki oleh semacam preoccupied knowledge tentang isu-isu tertentu dalam kajian keagamaan/keislaman sebelum dia terjun ke lapangan. ${ }^{45}$ Dalam konteks ini, penelitian empiris tentang Islam sebenarnya

${ }^{44}$ Lihat, misalnya, Amin Abdullah, Studi Agama: Normativitas atau Historisitas? (Yogyakarta: Pustaka Pelajar, 1996).

45Jacques Waardenburg membuat pernyataan menarik terkait studi Islam di Negara-negara Muslim. Menurutnya, pengkajian tentang Islam merupakan sebuah academic enterprise yang cukup menantang akibat banyaknya kendala-kendala yang ada di lapangan penelitian, seperti kendala etos akademik, kendala keterputusan konteks, kendala politik global, dan lain sebagainya. Lebih jauh mengenai hal ini, baca, Jacques Waardenburg, "Observations on the Scholarly Study of Religions as Pursued in some Muslim Countries", dalam Armin W. Geertz \& Russell T. McCutcheon (eds.), Perspectives on Method and Theory in the Study of Religion (Leiden: E.J. Brill, 2000), pp. 91-109. 
bisa saja dilakukan hanya sekadar untuk meneguhkan paradigma deduktif yang sudah mengendap di alam bawah sadar si peneliti atau akademisi, misalnya untuk meneguhkan teori-teori tertentu dari ilmu-ilmu keislaman, atau justru untuk mencari-cari justifikasi teks suci pada pengalaman empiris kehidupan umat beragama.

Penerapan paradigma deduktif dalam kancah penelitian sebenarnya bukan sesuatu yang dilarang. Pada awalnya tradisi penelitian positivistik juga berangkat dari semangat semacam ini. Kancah atau setting empiris hanya dijadikan sebagai logus pembuktian sebuah teori, apakah teori tersebut terbukti atau tidak di lapangan. Tradisi penelitian semacam ini pada tahap selanjutnya mendorong penerapan jenis penelitian kuantitatif dalam ilmu-ilmu sosial. Sebuah penelitian didorong oleh semangat membuktikan kebenaran sebuah teori. Dalam konteks ini, tidak ada istilah penemuan teori yang benar-benar baru dari kajian lapangan, karena seorang peneliti selalu membawa serta hipotesis yang acapkali berasal dari teori-teori sosial. Akibatnya, penelitian semacam ini seringkali membawa bias-bias subyektif terhadap kebenaran sebuah teori sebelum benar-benar diuji di lapangan.

Penelitian ilmu-ilmu keagamaan/keislaman sebenarnya jauh lebih kompleks dari sekadar penelitian yang bersifat positivistik. Penelitian kualitatif dalam bidang ini jauh lebih menantang karena membawa berbagai konsekuensi metodologis bagi sebuah kajian. Terlebih lagi, penelitian kualitatif berbasis paradigma induktif membawa implikasi pada pengayaan data lapangan, bukan sekadar penguatan bangunan argumentasi melalui permainan logika dan teori yang miskin data lapangan. Inilah kontribusi paling nyata dari paradigma induktif terhadap kajian keagamaan atau keislaman. Paradigma ini pula yang membuat kajian keagamaan/kesilaman menjadi lebih dinamis, membumi, dan kontekstual. Kajian keagamaan/keislaman tiba-tiba ditarik dari 'wilayah langit' yang dahulunya merupakan wilayah 'orangorang suci' memainkan peran profetiknya di atas panggung sejarah peradaban manusia.

Dalam konteks kajian Islam di Indonesia, penelusuran sejarah walisanga barangkali bisa dicontohkan sebagai lokus 
masuknya paradigm induktif ini. ${ }^{46}$ Penggunaan dua paradigma yang berbeda ini-antara induktif dan deduktif-dalam penelitian tentang sejarah walisanga sudah tentu akan menghasilkan kesimpulan atau narasi akademik yang berbeda. Paradigma deduktif cenderung memperlihatkan sisi-sisi magismitikal dari sosok walisanga sebagai representasi super buman yang berbeda dari manusia kebanyakan. Selain itu, penarasian sosok walisanga tidak akan banyak ditopang oleh bukti-bukti empiris tentang eksistensinya dalam kehidupan keagamaan di Jawa. Kajian-kajian semacam ini cenderung akan menghasilkan mistifikasi atas sosok walisanga. Jika sudah demikian, maka gambaran yang lebih obyektif tentang sosok walisanga dan kiprahnya berdasarkan data lapangan cenderung terkesampingkan.

Berbeda halnya jika penelitian tentang sejarah walisanga didekati melalui pendekatan induktif. Penelitian semacam ini akan mengasilkan narasi akademik yang lebih dinamis, kritis dan obyektif. Hal demikian terjadi karena penghadiran sosok walisanga dilakukan melalui penghadiran data empiris yang diperoleh melalui pendekatan sejarah sosial, arkeologi, dan semacamnya. Sebagai akibatnya, gambar tentang sejarah walisanga pasti jauh dari unsur-unsur magis dan mitikal, sebuah fenomena yang hanya tumbuh dari peradaban folklore. Penghadiran sosok walisanga akan tetap memperhatikan buktibukti sejarah dan arkeologi sebagaimana disediakan oleh sumber-sumber data seperti naskah kuno dan artefak budaya. Dari sini kita akan diberi informasi bahwa sosok walisanga bukanlah sekumpulan individu yang hidup pada satu kurun tertentu, melainkan pada kurun yang berbeda-beda. Mereka juga bukan sekelompok pendakwah yang saling terikat oleh komitmen yang dirumuskan secara bersama-sama.

Paradigma induktif juga dapat diterapkan dalam kajian tentang sejarah lembaga pondok pesantren di Jawa. Pada

${ }^{46}$ Dalam konteks sejarah Islam Jawa, Hurgronje, misalnya, pernah melontarkan kritik bahwa sumber-sumber sejarah local tentang walisanga tidak layak dijadikan referensi akademik karena mereka bersifat 'kekanakkanakan dan tanpa kronologis'. Baca, Berg, "The Islamization of Java," Studia Islamica, vol. 4 (1955): 116. 
umumnya buku-buku yang ditulis oleh kebanyakan sejarawan mencatat bahwa lembaga pesantren tertua dapat dijumpai pada zaman Sunan Ampel dan Sunan Giri, sekalipun asumsi teoretik ini tidak didukung dengan bukti-bukti fisik (hard facts) yang dapat dipertanggungjawabkan. ${ }^{47}$ Pada umumnya asumsi semacam ini dibangun di atas prinsip kemasukakalan (commonsensicality) logika yang disusun secara teoretik-deduktif; bahwa pesantren pertama didirikan oleh Sunan Ampel dan Sunan Giri karena alasan-alasan kemasukakalan belaka. Padahal kajian yang cukup serius tentang sejarah pesantren menghasilkan kesimpulan bahwa pesantren tertua di Indonesia—sejauh penelusuran arkeologis dilakukan atas jejak-jejak peninggalan sejarah—adalah pesantren Tegalsari di Ponorogo. ${ }^{48}$ Kesimpulan ini didasarkan pada ketersediaan fakta-fakta keras yang dapat dijumpai di lapangan.

Karya-karya penelitian yang dihasilkan melalui penerapan paradigma deduktif cenderung simplifikatif dan terjebak pada mistifikasi. Dalam kajian semacam ini, biasanya seorang peneliti atau penulis telah memiliki bias-bias pribadi yang bersifat bawah sadar dan menjadikannya sebagai misi ideologis yang dituangkan melalui serangkaian argumentasi yang dibangun dalam karyakarya akademiknya. Memang, bias pribadi merupakan sesuatu yang tidak dilarang dalam kajian ilmu-ilmu sosial-humaniora, bahkan merupakan hal yang wajar. Tetapi keterlibatan bias pribadi yang sudah menjurus pada masuknya kepentingan ideologis dalam kajian ilmiah cenderung menghasilkan kajian yang simplifikatif atau menyederhanakan masalah. Selain itu, hadirnya bias pribadi bisa juga didorong oleh keinginan tersembunyi dari pihak peneliti untuk melakukan proses-proses mistifikasi atas obyek kajiannya.

Berdasarkan uraian di atas, dapat disimpulkan bahwa penggunaan paradigma induktif dalam kajian keagamaan atau keislaman dapat dilakukan dengan cara membuat, membangun

${ }^{47}$ Teori semacam ini dapat dijumpai dengan mudah pada buku-buku daras tentang sejarah Islam di Indonesia sebagaimana diajarkan di sekolahsekolah, misalnya buku sejarah untuk siswa SMA kelas 2 yang ditulis oleh Tugiyono KS dkk dan Habib Mustopo dkk.

${ }^{48}$ Martin van Bruinessen, Kitab Kuning: Pesantren dan Tarekat Tradisi-tradisi Islam di Indonesia (Bandung: Mizan, 1995), 23-24. 
dan menguji premis-premis akademik tentang apa yang terjadi (realitas), bukan tentang apa yang seharusnya terjadi (idealitas). Sebagai akibatnya, data lapangan diperlakukan sebagai sesuatu yang sangat istimewa dalam kajian keagamaan. Sebuah kajian akan bernilai tinggi bukan semata karena faktor bobot permainan logika atau refleksi teoretik yang digunakan oleh sang peneliti atau penulis. Lebih dari itu, nilai kajian akan sangat ditentukan oleh sejauhmana sang peneliti atau penulis merangkai premis-premis ilmiahnya berdasar atas data lapangan yang kaya dan argumentatif. Kajian semacam ini, pada akhirnya, menciptakan sebuah harmoni ilmiah antara data, analisis dan teori secara berimbang dan berkesinambungan.

\section{Catatan Akhir}

Bahwa Islam, melalui al-Qur'an dan hadis, telah menekankan pentingnya penggunaan akal pikiran sebagai alat pencarian kebenaran merupakan sesuatu yang diketahui oleh hampir seluruh umat Muslim. Namun pertanyaan yang menggelitik untuk dijawab adalah; bagaimana setiap Muslim memaknai dan mengaktualisasikan kegiatan berpikir tersebut dalam praksis kehidupan? Pada umumnya, mayoritas umat Muslim hanya berhenti pada pemahaman bahwa Islam mendorong manusia untuk berpikir, tanpa mau merefleksikan secara kritis jenis berpikir seperti apa yang dapat mengantarkan umat Muslim menuju kejayaan peradaban. Inilah inti persoalan yang menjadi silang-sengkarut perdebatan umat Muslim tentang keterpurukan peradaban umat Muslim dewasa ini. Jika kita tidak cermat memformulasikan jawaban atas pertanyaan ini, bisa dipastikan konsep nalar dan ilmu pengetahuan akan dimaknai secara monolitik. Akibatnya, Islam dikhawatirkan tidak akan lagi mampu menggenggam kejayaan peradaban sebagaimana pada Abad Keemasan dulu.

Memang tidak ada jawaban tunggal terhadap silangsengkarut di atas. Banyak hal melatarbelakangi mengapa jalan menuju Pencerahan terasa berat bagi umat Muslim. Hal pertama adalah terabaikannya paradigma induktif dalam hampir setiap proses ilmiah. Artinya, umat Muslim lebih banyak mengandalkan kekuatan paradigma deduktif dalam proses ilmiah. Akibatnya, 
pengembangan ilmu pengetahuan dan teknologi dalam Islam berjalan kurang dinamis dan inovatif. Padahal dinamika ilmu pengetahuan meniscayakan perubahan-perubahan ilmu pengetahuan secara cepat. Menurut catatan para ilmuwan, teori ilmu pengetahuan berubah setiap 20 menit. Oleh karena itu, perlakuan umat Muslim terhadap kitab suci sebagai sesuatu yang sejajar dengan sains merupakan sikap yang fatal karena mengandaikan perubahan isi kitab dalam setiap 20 menit!

Kedua, umat Muslim harus memilah-milah secara kritis apa dan bagaimana kegiatan berpikir didefinisikan. Hal ini penting karena tidak semua kegiatan yang melibatkan nalar atau otak bisa disebut berpikir. Ada banyak variasi berpikir dalam kehidupan manusia; ada berpikir menggunakan kesadaran kognitif, berpikir dengan kesadaran hati, berpikir dengan kesadaran budi dan nurani, dan lain sebagainya. Mengikuti konstruk teoretik Abid alJabiri, kegiatan berpikir itu ada tiga: bayani, burbani dan irfani. ${ }^{49}$ Bayani adalah kegiatan berpikir deduktif yang dibimbing oleh ketentuan teks wahyu dan bersifat legal-formal-normatif. Irfani adalah kegiatan berpikir spiritual yang dibimbing oleh kesadaran transendental-ruhani. Sementara itu, burhani adalah kegiatan berpikir induktif yang bersifat empiris dan lebih mengedepankan pada serangkaian uji laboratorium.

Dalam konteks kajian keagamaan/keislaman, penerapan paradigma induktif dapat dilakukan melalui pembuatan narasi akademis melalui pengayaan data lapangan. Preposisi dan premis ilmiah yang dibangun oleh sang peneliti tidak semata-mata didasarkan pada kemasukakalan (commonsensicality) belaka, namun didasarkan pada soliditas data keras di lapangan. Paradigma ini tecermin pada pergeseran kajian keagamaan yang berbasis pada studi lapangan ketimbang studi teoretik atau kajian literatur. Nilai sebuah kajian ilmiah, salah satunya, ditentukan oleh sejauhmana seorang peneliti mampu membangun argumentasi akademik berdasarkan pada serangkaian fakta-fakta keras yang solid. Dengan cara demikian, kajian keagamaan/keislaman akan menjadi hidup, dinamis dan terbebas dari mistifikasi obyek kajian. Wa al-Lāh a lam bi al-șawäb.

${ }^{49}$ Muhammad Ābīd al-Jābirī, Bunyah al-'Aql al-'Arabì (Beirut: al-Markaz al-Thaqafi al-'Arabi, 1993). 


\section{Daftar Pustaka}

Abdullah, M. Amin. 1996. Studi Agama: Normativitas atau Historisitas? Yogyakarta: Pustaka Pelajar.

Al-Andalusi, Sa'id. 1991. Science in the Medieval World: "Book of the Categories of Nations. Austin, Texas: The University of Texas Press.

Al-Jābirī, Muhammad Ābīd. 1993. Bunyah al-'Aql al-'Arabì. Beirut: al-Markaz al-Thaqafi al-'Arabi.

An-Najjar, Zaghlul. 2011. Sains dalam Hadis: Mengungkap Fakta Ilmiah dari Kemukjizatan Hadis Nabi. Jakarta: Amzah.

Ayoub, Mahmoud M. 2005, "Creation or Evolution? The

Reception of Darwinism in Modern Arab Thought", dalam

Zainal Abidin Bagir (ed.), Science and Religion in a post-Colonial

World: Interfaith Perspectives. Adelaide: ATF Press: 173-190.

Berg, C.C. "The Islamization of Java," Studia Islamica, vol. 4 (1955): 111-42.

Bucaille, Maurice. 1976. The Bible, the Qur'an and Science, terj.

Alastair D. Pannel and penulisnya. Tripoli: Islamic Call Society.

Deravi, Farzin. 2006. "Scientific Method and the Quest for Objective Knowledge", dalam Rais Ahmad, Islam and Scientific Debate: Searching for Legitimacy. New Delhi: Global Vision Publishing House.

Dizer, Muammar. 2001. "Observatories and Astronomical Instruments," dalam A.Y. al-Hassan (ed.), Science and Technology in Islam. Paris \& Beirut: UNESCO Publishing.

Dreyer, John Luis Emil. 1953. History of Astronomy from Thales to Kepler. New York: Dover Publications.

Edis, Taner. 2007. An Illusion of Harmony: Science and Religion in Islam. New York: Prometheus Books.

Endress, Gerhard. 2003. "Mathematics and Philosophy in Medieval Islam", dalam Jan P. Hogendijk \& Abdelhamid I. Sabra (eds.), The Enterprise of Science in Islam: New Perspectives. Massachusetts: Massachusetts Institute of Technology.

Engel, Rafael J. \& Russell K. Schutt. 2010. Fundamentals of Social Work Research. California \& New Delhi: Sage Publication. 
Al-Gazālī, Abū Hamid. 1987. Iḅya 'Ulūm al-Dìn, jilid I. Bayrut: Dār al-Fikr.

Heit, Evan. 2007. "What Is Induction and Why Study It?", dalam Aidan Feeney \& Evan Heit (eds.), Inductive Reasoning: Experimental, Developmental and Computational Approaches. Cambridge: Cambridge University Press,.

bttp:/ / www.harunyabya.com.

Iqbal, Sir Muhammad. 2013. The Reconstruction of Religious Thought in Islam. Stanford, California: Stanford University Press.

Lameer, Joep. 1994. Al-Farabi \& Aristotelian Syllogistics: Greek Theory \& Islamic Practice. Leiden: E.J. Brill.

Moore, Rob. 2009. Towards the Sociology of Truth. London \& New

York: Continuum International Publishing Group.

Oaksford, Mike \& Nick Chater. 2002. "Commonsense reasoning, Logic, and Human Rationality", dalam Renèe Elio (ed.). Common Sense, Reasoning, and Rationality. Oxford: Oxford University Press.

Qadir, C.A. 1988. Philosophy and Science in the Islamic World. London: Routledge.

Salam, Muhammad Abdus. 1994. Renaissance of Sciences in Islamic Countries. Singapore: World Scientific Publishing.

Saliba, George. 2007. Islamic Science and the making of the European Renaissance. Cambridge \& London: The MIT Press.

Sayli. 1998. The Observatory in Islam. Frankfurt: Institute for the History of Arabic-Islamic Science at the Johann Wolfgang Goethe University.

Scheibe, Erhard. 2001. Between Rationalism and Empiricism: Selected Papers in the Philosophy of Physics. Berlin: Springer-Verlag.

Shavanas, T.O. 2005. Creation And/or Evolution: An Islamic Perspective. Bloomington, Indiana: Xlibris Corporation. . 2010. Islamic Theory of Evolution: The Missing Link between Darwin and the Origin of Species. London: Brainbow Press.

Stark, Werner. 1991. The Sociology of Knowledge: Toward a Deeper Understanding of the History of Ideas. New Jersey: Transaction Publications.

Suriasumantri, Jujun S. 2005. Filsafat Ilmu: Sebuah Pengantar Populer. Jakarta: Pustaka Sinar Harapan. 
Thayyarah, Nadiah. 2013. Buku Pintar Sains dalam al-Qur'an. Jakarta: Zaman

van Bruinessen, Martin. 1995. Kitab Kuning: Pesantren dan Tarekat Tradisi-tradisi Islam di Indonesia. Bandung: Mizan, 23-24.

Waardenburg, Jacques. 2000. "Observations on the Scholarly Study of Religions as Pursued in some Muslim Countries", dalam Armin W. Geertz \& Russell T. McCutcheon (eds.), Perspectives on Method and Theory in the Study of Religion. Leiden: E.J. Brill : 91-109.

Walbridge, John. 2011. God and Logic in Islam: The Caliphate of Reason. Cambridge: Cambridge University Press.

Watson, Richard A. 1987. The Breakdown of Cartesian Metaphysics. Cambridge, MA: Hackett Publishing.

Wells, H.G. 1951. The Outline of History: Being a Plain History of Life and Mankind. New York: P.F. Collier \& Son Company.

Yahya, Harun. 2003. Why Darwinism is Incompatible with the Qur'an. Istanbul: Global Yayincilik. 